\title{
North African vegetation-precipitation feedback in early and mid-Holocene climate simulations with CCSM3-DGVM
}

\author{
R. Rachmayani ${ }^{1}$, M. Prange ${ }^{1,2}$, and M. Schulz ${ }^{1,2}$ \\ ${ }^{1}$ Faculty of Geosciences, University of Bremen, Klagenfurter Strasse, 28334 Bremen, Germany \\ ${ }^{2}$ MARUM - Center for Marine Environmental Sciences, University of Bremen, Leobener Strasse, 28359 Bremen, Germany \\ Correspondence to: R. Rachmayani (rrachmayani@marum.de)
}

Received: 14 April 2014 - Published in Clim. Past Discuss.: 12 May 2014

Revised: 30 December 2014 - Accepted: 6 January 2015 - Published: 6 February 2015

\begin{abstract}
The present study analyses the sign, strength, and working mechanism of the vegetation-precipitation feedback over North Africa in middle (6 kaBP) and early Holocene $(9 \mathrm{kaBP})$ simulations using the comprehensive coupled climate-vegetation model CCSM3-DGVM (Community Climate System Model version 3 and a dynamic global vegetation model). The coupled model simulates enhanced summer rainfall and a northward migration of the West African monsoon trough along with an expansion of the vegetation cover for the early and middle Holocene compared to the pre-industrial period. It is shown that dynamic vegetation enhances the orbitally triggered summer precipitation anomaly by approximately $20 \%$ in the Sahara-Sahel region $\left(10-25^{\circ} \mathrm{N}, 20^{\circ} \mathrm{W}-30^{\circ} \mathrm{E}\right)$ in both the early and midHolocene experiments compared to their fixed-vegetation counterparts. The primary vegetation-rainfall feedback identified here operates through surface latent heat flux anomalies by canopy evaporation and transpiration and their effect on the mid-tropospheric African easterly jet, whereas the effects of vegetation changes on surface albedo and local water recycling play a negligible role. Even though CCSM3-DGVM simulates a positive vegetation-precipitation feedback in the North African region, this feedback is not strong enough to produce multiple equilibrium climate-ecosystem states on a regional scale.
\end{abstract}

\section{Introduction}

At present, North Africa is much drier than during the early and middle Holocene when a higher orbitally induced summer insolation triggered more humid and "greener" conditions in the Sahel and Saharan regions (e.g. Kutzbach and Street-Perrot, 1985; Street-Perrott and Perrott, 1993; Jolly et al., 1998; Kohfeld and Harrison, 2000; Prentice et al., 2000; Bartlein et al., 2011; Collins et al., 2013). Following pioneering modelling work by Kutzbach (1981), numerous numerical climate model experiments have been conducted in order to examine climate sensitivity to Holocene orbital forcing at low latitudes, where insolation variations are strongly dominated by the precessional cycle. Even though these model studies have abundantly documented that an intensification and northward shift of the North African summer monsoon was induced by the enhanced seasonal insolation cycle during the early to mid-Holocene, rainfall anomalies simulated by the models turned out to be significantly smaller than those reconstructed from lake level or pollen data (e.g. Jolly et al., 1998; Kohfeld and Harrison, 2000). Therefore, various positive feedbacks have been postulated to be crucial in shaping the early to mid-Holocene North African humid period, involving vegetation and soil (e.g. Kutzbach et al., 1996; Claussen et al., 1999; Doherty et al., 2000; Levis et al., 2004a; Hales et al., 2006), sea-surface temperatures (e.g. Kutzbach and Liu, 1997; Zhao et al., 2005; Zhao and Harrison, 2012), and surface-water coverage by lakes and wetlands (e.g. Coe and Bonan, 1997; Krinner et al., 2012). Over time, the notion of a positive vegetation-precipitation feedback has received the greatest attention in the literature (see Claussen, 2009). 
Based on early work by Otterman (1974) and Charney (1975), it has been suggested that the effect of an expanded North African vegetation cover on surface albedo would be key in amplifying the early to mid-Holocene West African monsoonal rainfall (e.g. Claussen and Gayler, 1997; Brovkin et al., 1998; Hales et al., 2006). Provided that the positive vegetation-climate feedback is sufficiently strong to introduce non-linear dynamics into the climate-vegetation system, multiple equilibria of the atmosphere-vegetation state may exist (Claussen, 1994, 1997, 1998; Wang and Eltahir, 2000; Zheng and Neelin, 2000; Renssen et al., 2003; Patricola and Cook, 2008; Bathiany et al., 2012): a humid state with expanded vegetation cover and an arid state with an expanded desert. In general circulation and conceptual model studies, bistability was found only under late Holocene (i.e. after $\sim 6 \mathrm{kaBP}$ ) orbital forcing, while only one stable state, the "green (western part of the) Sahara", was found for early to mid-Holocene forcing (Claussen and Gayler, 1997; Brovkin et al., 1998; Claussen et al., 1998).

A transition from the humid state to the arid state by a catastrophic bifurcation or "unstable collapse" (Liu et al., 2006, 2007) was suggested to have abruptly terminated the African humid period around $5.5 \mathrm{kaBP}$ (deMenocal et al., 2000). Both the abruptness of the North African climate transition (Renssen et al., 2006a; Kröpelin et al., 2008; Lézine et al., 2011; Claussen et al., 2013; Francus et al., 2013) as well as the existence of a strong positive vegetationrainfall feedback in North Africa (Levis et al., 2004a; Liu et al., 2006, 2007; Kröpelin et al., 2008; Notaro et al., 2008; Wang et al., 2008; Liu et al., 2010) were later challenged. In a model intercomparison study, two out of three coupled climate-vegetation models that participated in PMIP2 (Paleoclimate Modelling Intercomparison Project, Phase II) suggested a negative vegetation-precipitation feedback over North Africa in simulations of the middle Holocene, though no systematic feedback analysis was performed (Braconnot et al., 2007). In particular, the Charney feedback operating via surface albedo changes has been called into question (Levis et al., 2004a; Notaro et al., 2008; Patricola and Cook, 2008; Wang et al., 2008; Liu et al., 2010).

In the current study, we investigate the sign, strength, and working mechanism of the vegetation-precipitation feedback over North Africa in mid (6 ka BP) and early Holocene (9 ka BP) simulations with the comprehensive fully coupled climate-vegetation model CCSM3-DGVM (Community Climate System Model version 3 and a dynamic global vegetation model). In contrast to statistical (lagged autocovariance) approaches (e.g. Notaro et al., 2008; Wang et al., 2008) to assess the existence and sign of the biogeophysical feedback, we apply a straightforward experimental design to assess the climate-vegetation feedback in North Africa by switching on and off interactive dynamic vegetation in this specific coupled model. Moreover, the impact of vegetation initial conditions on mid-Holocene and modern (pre-industrial) climatevegetation simulations and hence the existence of multiple equilibria in the North African climate-vegetation system is studied systematically.

\section{Experimental design}

\subsection{Model}

The National Center for Atmospheric Research (NCAR) Community Climate System Model version 3 is composed of four components representing atmosphere, ocean, land (including the DGVM), and sea ice connected by a flux coupler (Collins et al., 2006). Here we use the low-resolution version of the model, in which the resolution of the atmosphere and land components is given by T31 ( $3.75^{\circ}$ transform grid), while the ocean has a nominal horizontal resolution of $3^{\circ}$ (Yeager et al., 2006). The atmospheric and oceanic grids have 26 and 25 levels in the vertical, respectively. New parameterizations for canopy interception and soil evaporation have been implemented into the land component in order to improve the simulation of the land hydrology and vegetation cover (Oleson et al., 2008) as in Handiani et al. (2013). CCSM3's dynamic-vegetation model DGVM is based on the Lund-Potsdam-Jena (LPJ) model (Sitch et al., 2003; Levis et al., 2004b; Bonan and Levis, 2006) and simulates the spatiotemporal distribution of 10 plant functional types (PFTs; 7 tree PFTs and 3 grass PFTs) which are differentiated by physiological, morphological, phenological, bioclimatic, and fire-response attributes (Levis et al., 2004b). The land and atmosphere components are integrated with a 30 min time step, while vegetation structure and PFT population densities are updated annually (Levis et al., 2004b).

\subsection{Setup of experiments}

In order to disentangle the impact of dynamic vegetation on the early and mid-Holocene North African climate, three sets of experiments were carried out. The first set (OAV) uses the fully coupled CCSM3-DGVM including dynamic ocean $(\mathrm{O})$, atmosphere $(\mathrm{A})$, and vegetation $(\mathrm{V})$ components as described above. A pre-industrial (PI) control run of CCSM3-DGVM was performed following the PMIP2 protocol with respect to the forcing (Braconnot et al., 2007). The PI simulation was integrated for 1000 years upon initialization with present-day hydrographic data and bare soil. Branching off from year 600 of the PI run, a middle ( $6 \mathrm{ka} \mathrm{BP})$ and an early Holocene $(9 \mathrm{kaBP})$ climate simulation was performed, each integrated for 400 years. Table 1 summarizes radiative forcings used in the set of model runs. Since variations in greenhouse gas concentrations over the three time slices are minor, the major forcing comes from variations in the Earth's orbital parameters. The orbitally induced summer insolation anomaly is larger at $9 \mathrm{ka} \mathrm{BP}$ than at $6 \mathrm{ka}$ BP (Berger, 1978). The experiments with dynamic vegetation are referred to as $0 \mathrm{k}(\mathrm{OAV}), 6 \mathrm{k}(\mathrm{OAV})$, and $9 \mathrm{k}(\mathrm{OAV})$. To examine the role of DGVM initial conditions and the 
Table 1. Summary of boundary conditions used in the experiments. Summer insolation refers to 21 July at $20^{\circ} \mathrm{N}$.

\begin{tabular}{lcccc}
\hline Experiments & $\begin{array}{c}\mathrm{CO}_{2} \\
(\text { ppmv })\end{array}$ & $\begin{array}{c}\mathrm{CH}_{4} \\
(\mathrm{ppbv})\end{array}$ & $\begin{array}{c}\mathrm{N}_{2} \mathrm{O} \\
(\mathrm{ppbv})\end{array}$ & $\begin{array}{c}\text { Summer insolation } \\
\left(\mathrm{W} \mathrm{m}^{-2}\right)\end{array}$ \\
\hline 0k (PI) & 280 & 760 & 270 & 453 \\
6k (mid-Holocene) & 280 & 650 & 270 & 477 \\
9k (early Holocene) & 265 & 680 & 260 & 486 \\
\hline
\end{tabular}

potential for bistable climate-vegetation states, two additional 400-year-long CCSM3-DGVM simulations for PI and the mid-Holocene were carried out, which were also initialized from year 600 of $0 \mathrm{k}(\mathrm{OAV})$ except for the vegetation cover (PFT distribution), which was taken from the final state of the $9 \mathrm{k}(\mathrm{OAV})$ experiment. These simulations are denoted by $0 \mathrm{k} 9 \mathrm{k}(\mathrm{OAV})$ and $6 \mathrm{k} 9 \mathrm{k}(\mathrm{OAV})$.

In the second set of experiments $\left(\mathrm{OAV}_{\mathrm{f}}\right)$, the global PFT distribution is fixed. Three experiments with PI, $6 \mathrm{ka} \mathrm{BP}$, and $9 \mathrm{kaBP}$ boundary conditions (Table 1) were integrated for 400 years (again branching off from year 600 of $0 \mathrm{k}(\mathrm{OAV})$ ) using the fixed vegetation cover taken from the final state of experiment $0 \mathrm{k}(\mathrm{OAV})$. These experiments are denoted by $0 \mathrm{k}\left(\mathrm{OAV}_{\mathrm{f}}\right), 6 \mathrm{k}\left(\mathrm{OAV}_{\mathrm{f}}\right)$, and $9 \mathrm{k}\left(\mathrm{OAV}_{\mathrm{f}}\right)$. The third set of experiments $(\mathrm{OA})$ is identical to the $\mathrm{OAV}_{\mathrm{f}}$ set of experiments, except that the observation-based modern vegetation cover from the standard CCSM3 setup without DGVM was prescribed. These runs are referred to as experiments $0 \mathrm{k}(\mathrm{OA})$, $6 \mathrm{k}(\mathrm{OA})$, and $9 \mathrm{k}(\mathrm{OA})$.

In all simulations, ozone and aerosol distributions were kept at pre-industrial levels (Otto-Bliesner et al., 2006) and a fixed solar constant of $1365 \mathrm{~W} \mathrm{~m}^{-2}$ was applied. Moreover, all experiments were run with a modern ice-sheet configuration and global sea level. For model output analyses, averages of the last 100 simulation years from each experiment were used and are presented here. Since this study focusses on the West African summer monsoon system, the analysis of climatologic quantities is limited to the months of June through September (JJAS). Note that a fixed calendar based on 365 days per year with vernal equinox fixed to March 21 (the day and month values refer to the present calendar) is used for all experiments (Joussaume and Braconnot, 1997; Chen et al., 2011). However, this does not affect the comparison of the different experiments for identical time slices.

\section{Results}

The North African vegetation cover from the $0 \mathrm{k}(\mathrm{OAV})$ control run is shown in Fig. 1, where the 10 PFTs simulated by the model are combined into two groups (trees and grasses). North of $18^{\circ} \mathrm{N}$ the model simulates desert with almost no vegetation. Between 12 and $18^{\circ} \mathrm{N}$, a semi-arid belt dominated by $\mathrm{C}_{4}$ grass vegetation is simulated. To the south, the simulated vegetation cover mostly consists of trees in cen-

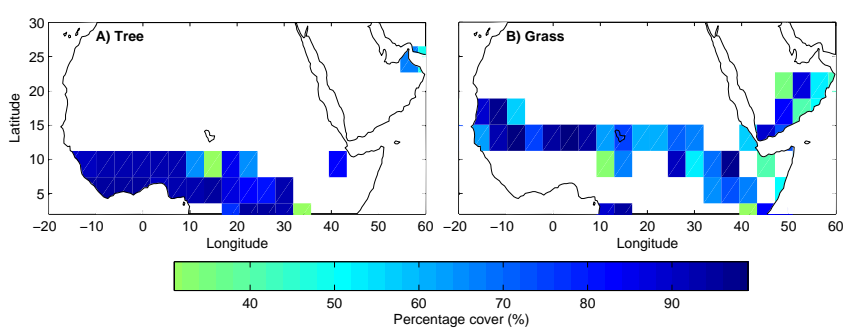

Figure 1. Pre-industrial vegetation cover over North Africa simulated by CCSM3-DGVM. (a) Percentage coverage of tree PFTs; (b) the same for grasses.

tral and western tropical Africa. Similar to earlier dynamicvegetation modelling studies (Bonan et al., 2003; Sitch et al., 2003; Oleson et al., 2008), CCSM3-DGVM produces too much forest cover south of the Sahel compared to satellite observations (DeFries et al., 1999, 2000; Lawrence and Chase, 2007). Applying mid-Holocene boundary conditions in experiment $6 \mathrm{k}(\mathrm{OAV})$ results in a northward expansion of the North African vegetation cover (Fig. 2a), which is even more pronounced in experiment $9 \mathrm{k}(\mathrm{OAV})$ under early Holocene boundary conditions (Fig. 2b). The vegetation increase also captures the Arabian Peninsula and is mostly due to the expansion of grasses.

Figure 3a and $\mathrm{b}$ support that the greening of North Africa in the early to mid-Holocene is associated with enhanced summer (JJAS) precipitation over this region, with largest rainfall anomalies between 10 and $25^{\circ} \mathrm{N}$. Averaged over this latitude range and between $20^{\circ} \mathrm{W}-30^{\circ} \mathrm{E}$, the mid-Holocene summer rainfall anomaly amounts to $0.97 \mathrm{~mm} \mathrm{day}^{-1}$ and lies well within the range of previously published $6 \mathrm{ka}$ BP climate model simulations (Braconnot et al., 2007). For the $9 \mathrm{k}(\mathrm{OAV})$ simulation, the summer rainfall anomaly over this region is even larger $\left(1.27 \mathrm{~mm} \mathrm{day}^{-1}\right)$ due to stronger orbital forcing (Table 1). Southwesterly surface wind anomalies between 15 and $25^{\circ} \mathrm{N}$ indicate that the enhanced precipitation is associated with a northward expansion of monsoon winds and a northward displacement of the monsoon trough (Fig. 3a and $b$ ).

In the simulations with fixed modern vegetation biogeography $\left(\mathrm{OAV}_{\mathrm{f}}\right)$, the middle and early Holocene rainfall anomalies over North Africa are significantly smaller compared to their OAV counterparts (Fig. 3c-f). Averaged over the Sahara-Sahel region of $10-25^{\circ} \mathrm{N}, 20^{\circ} \mathrm{W}-30^{\circ} \mathrm{E}$, the summer anomalies amount to only 0.80 and $1.04 \mathrm{~mm} \mathrm{day}^{-1}$ for experiments $6 \mathrm{k}\left(\mathrm{OAV}_{\mathrm{f}}\right)$ and $9 \mathrm{k}\left(\mathrm{OAV}_{\mathrm{f}}\right)$, respectively, relative to PI. This result indicates a positive vegetation-precipitation feedback in North Africa. For both the 6 and $9 \mathrm{ka} \mathrm{BP}$ time slices, the implementation of the interactively coupled DGVM into the climate model enhances the orbitally triggered rainfall anomaly over the Sahara-Sahel region by approximately $20 \%$. Experiments without dynamic vegetation using the standard CCSM3 setup (OA) yield early and mid-Holocene 
Table 2. Mean summer (JJAS) precipitation over the region 10 $25^{\circ} \mathrm{N}, 20^{\circ} \mathrm{W}-30^{\circ} \mathrm{E}$ in the various experiments. $\Delta P$ denotes anomalies relative to the corresponding $0 \mathrm{k}(\mathrm{PI})$ case. SE is the standard error. Precipitation values are normally distributed according to a Shapiro-Wilk normality test ( $95 \%$ confidence level).

\begin{tabular}{|c|c|c|}
\hline Experiments & $\begin{array}{l}\text { Precipitation }(P) \pm 2 \mathrm{SE} \\
\quad\left(\mathrm{mm} \mathrm{day}^{-1}\right)\end{array}$ & $\begin{array}{c}\Delta P \\
\left(\mathrm{~mm} \mathrm{day}^{-1}\right)\end{array}$ \\
\hline $0 \mathrm{k}(\mathrm{OAV})$ & $2.44 \pm 0.04$ & \\
\hline $6 \mathrm{k}(\mathrm{OAV})$ & $3.41 \pm 0.04$ & 0.97 \\
\hline 9k(OAV) & $3.71 \pm 0.04$ & 1.27 \\
\hline $0 \mathrm{k}\left(\mathrm{OAV}_{\mathrm{f}}\right)$ & $2.47 \pm 0.04$ & \\
\hline $6 \mathrm{k}\left(\mathrm{OAV}_{\mathrm{f}}\right)$ & $3.27 \pm 0.06$ & 0.80 \\
\hline $9 \mathrm{k}\left(\mathrm{OAV}_{\mathrm{f}}\right)$ & $3.51 \pm 0.06$ & 1.04 \\
\hline $0 \mathrm{k}(\mathrm{OA})$ & $2.48 \pm 0.04$ & \\
\hline $6 \mathrm{k}(\mathrm{OA})$ & $3.29 \pm 0.04$ & 0.81 \\
\hline $9 \mathrm{k}(\mathrm{OA})$ & $3.47 \pm 0.06$ & 0.99 \\
\hline 0k9k(OAV) & $2.47 \pm 0.06$ & $<2 \mathrm{SE}$ \\
\hline 6k9k(OAV) & $3.42 \pm 0.04$ & 0.98 \\
\hline
\end{tabular}

rainfall anomalies over North Africa that are similar to the $\mathrm{OAV}_{\mathrm{f}}$ results (Table 2).

The wetter North African conditions in the early and midHolocene OAV experiments compared to their $\mathrm{OAV}_{\mathrm{f}}$ counterparts are not associated with a wholesale strengthening of the southwesterly monsoon flow that transports moist air from the equatorial Atlantic to the continent (Fig. 3e and f). However, spatially coherent anomalies in the wind system over North Africa can be found at mid-tropospheric levels related to changes in the African easterly jet (AEJ), which constitutes the equatorward portion of the Saharan high and dominates the sub-Saharan summer circulation over West Africa between 10 and $20^{\circ} \mathrm{N}$ with maximum wind speeds between 700 and $500 \mathrm{hPa}$. In all early and mid-Holocene simulations, a westerly wind anomaly develops at mid-levels south of $\approx 15^{\circ} \mathrm{N}$, representing a weakening of the AEJ's southern flank relative to the modern situation, while the jet slightly intensifies at its northern flank (Fig. 4a-d), implying a northward shift of the jet. This behaviour is more pronounced in the OAV simulations than in their non-DGVM counterparts $\mathrm{OAV}_{\mathrm{f}}$ (Fig. 4e and f).

A close relationship exists between surface-temperature anomalies and mid-level wind anomalies over West Africa (Fig. 4). According to the thermal wind relation, anomalous horizontal temperature gradients induce vertical shear such that negative low-level temperature anomalies (communicated into the lower troposphere from the surface) are on the left of the anomalous mid-level wind vectors (cf. Cook, 1999). The negative surface-temperature anomalies in the early and mid-Holocene experiments are substantial (more than $6 \mathrm{~K}$ in the OAV experiments despite larger incoming shortwave radiation at the top of the atmosphere), in line with temperature reconstructions from groundwater samples (Beyerle et al., 2003), and are associated with increased

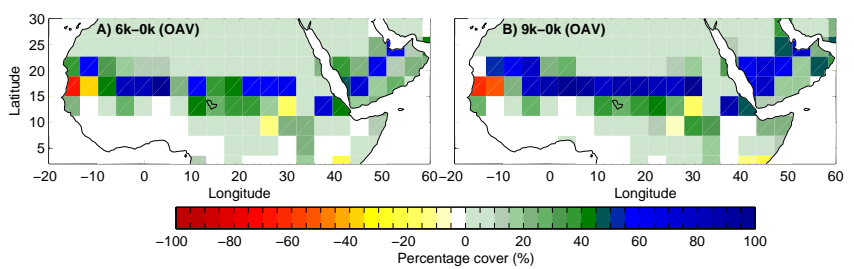

Figure 2. Change in total (i.e. all PFTs) percent vegetation cover for (a) the mid-Holocene (6 ka BP) and (b) the early Holocene (9 ka BP) experiment relative to the pre-industrial period (PI).

cloudiness due to enhanced convection, reflecting solar radiation back to space (cf. Braconnot et al., 2007; Patricola and Cook, 2007; Bosmans et al., 2012). Enhanced latent surface cooling by larger evapotranspiration in the wetter regions is even more relevant in the context of vegetation-rainfall feedbacks. Table 3 summarizes the changes in the different components of surface evapotranspiration over the SaharaSahel region for the set of experiments. With enhanced rainfall in the early and mid-Holocene experiments, evapotranspiration increases. This increase is much stronger when dynamic vegetation is enabled (OAV) due to enhanced canopy evaporation and transpiration in the "greener" regions. In the early and mid-Holocene experiments with fixed vegetation $\left(\mathrm{OAV}_{\mathrm{f}}\right.$ and $\left.\mathrm{OA}\right)$ changes in canopy evaporation and transpiration are negligible, whereas ground evaporation substantially increases. This increase in ground evaporation, however, is smaller than the rise in total evapotranspiration in the OAV experiments. As a result, latent surface cooling and hence changes in the AEJ are much more pronounced in the early and mid-Holocene experiments with dynamic vegetation (Fig. 4e and f).

Previous work has shown that the AEJ plays a key role in controlling sub-Saharan precipitation by transporting moisture off the continent below the level of condensation, thus increasing moisture divergence over West Africa (e.g. Cook, 1999; Rowell, 2003). Figure 5 displays moisture transport anomalies at the AEJ level for the early and mid-Holocene experiments. In all experiments, eastward moisture flux anomalies appear at the southern flank of the AEJ south of $15^{\circ} \mathrm{N}$, effectively reducing the westward moisture export from the North African region to the Atlantic. Owing to a stronger mid-level circulation change, the moisture export across the West African coastline is more strongly reduced in the early and mid-Holocene experiments with interactive dynamic vegetation compared to their fixed-vegetation counterparts (Fig. 5e and f), thus keeping more moisture available to feed the rain in the West African monsoon region.

Initializing the $0 \mathrm{k}$ and $6 \mathrm{k}$ simulations of CCSM3-DGVM with the expanded North African vegetation cover from experiment $9 \mathrm{k}(\mathrm{OAV})$ (cf. Fig. 2b) rather than with bare soil has a negligible effect on the region-averaged $\left(10-25^{\circ} \mathrm{N}\right.$, $20^{\circ} \mathrm{W}-30^{\circ} \mathrm{E}$ ) precipitation and evapotranspiration (see experiments $0 \mathrm{k} 9 \mathrm{k}(\mathrm{OAV})$ and $6 \mathrm{k} 9 \mathrm{k}(\mathrm{OAV})$ in Tables 2 and 3$)$. 

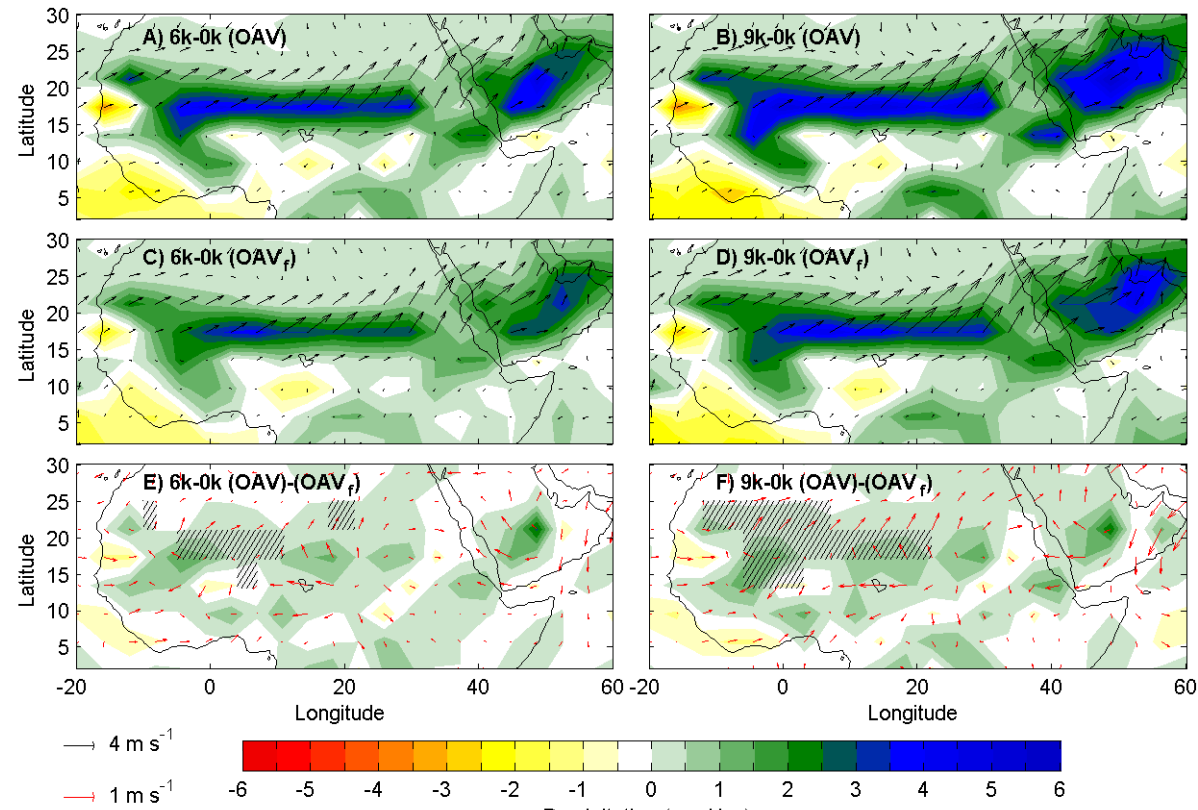

Longitude

Precipitation (mm/day)

Figure 3. Changes in summer precipitation and near-surface winds for (a) the mid-Holocene and (b) the early Holocene experiment relative to PI in model simulations with dynamic vegetation. (c, d): same as (a, b) but for fixed-vegetation simulations. (e, d): differences between dynamic-vegetation and fixed-vegetation experiments. Hatched areas in (e, f) display significant precipitation differences ( $95 \%$ confidence level) according to both a (non-parametric) Wilcoxon-Mann-Whitney test and a Student's $t$ test.
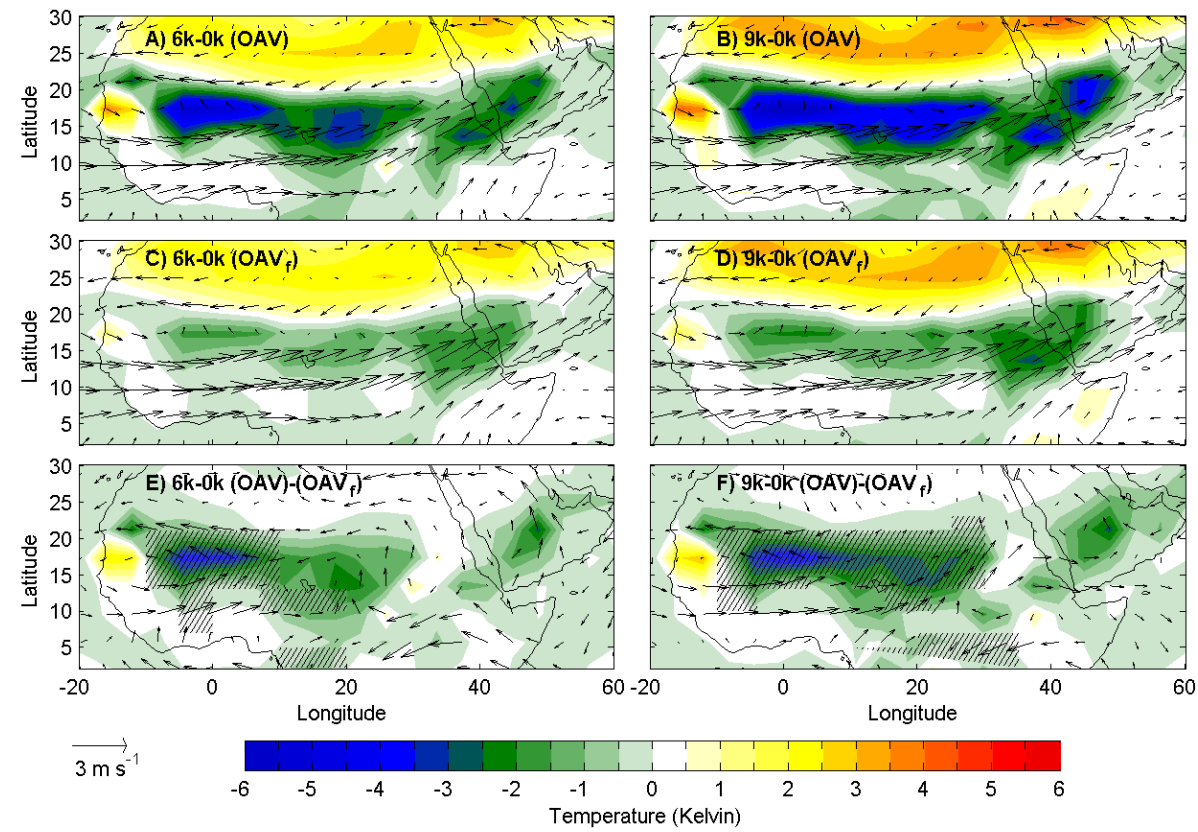

Figure 4. As in Fig. 3 but for changes in summer surface temperature and $700 \mathrm{hPa}$ winds. Hatched areas in (e, f) display significant temperature differences (95\% confidence level) according to both a (non-parametric) Wilcoxon-Mann-Whitney test and a Student's $t$ test. 
Table 3. Changes of summer (JJAS) canopy evaporation, canopy transpiration, and ground evaporation in the various early and mid-Holocene experiments over the region $10-25^{\circ} \mathrm{N}, 20^{\circ} \mathrm{W}-30^{\circ} \mathrm{E}$.

\begin{tabular}{|c|c|c|c|}
\hline Experiments & $\begin{array}{l}\text { Canopy evaporation } \\
\left(\mathrm{mm} \mathrm{day}{ }^{-1}\right)\end{array}$ & $\begin{array}{l}\text { Canopy transpiration } \\
\left(\mathrm{mm} \mathrm{day}^{-1}\right)\end{array}$ & $\begin{array}{l}\text { Ground evaporation } \\
\qquad\left(\mathrm{mm} \mathrm{day}^{-1}\right)\end{array}$ \\
\hline $6 \mathrm{k}-0 \mathrm{k}(\mathrm{OAV})$ & 0.18 & 0.23 & 0.06 \\
\hline $9 \mathrm{k}-0 \mathrm{k}(\mathrm{OAV})$ & 0.23 & 0.29 & 0.11 \\
\hline $6 \mathrm{k}-0 \mathrm{k}\left(\mathrm{OAV}_{\mathrm{f}}\right)$ & 0.00 & -0.03 & 0.34 \\
\hline $9 \mathrm{k}-0 \mathrm{k}\left(\mathrm{OAV}_{\mathrm{f}}\right)$ & 0.00 & -0.03 & 0.45 \\
\hline 6k-0k(OA) & 0.00 & -0.01 & 0.29 \\
\hline $9 \mathrm{k}-0 \mathrm{k}(\mathrm{OA})$ & 0.07 & 0.04 & 0.23 \\
\hline 0k9k-0k(OAV) & 0.03 & 0.04 & -0.04 \\
\hline $6 \mathrm{k} 9 \mathrm{k}-0 \mathrm{k}(\mathrm{OAV})$ & 0.18 & 0.22 & 0.07 \\
\hline
\end{tabular}

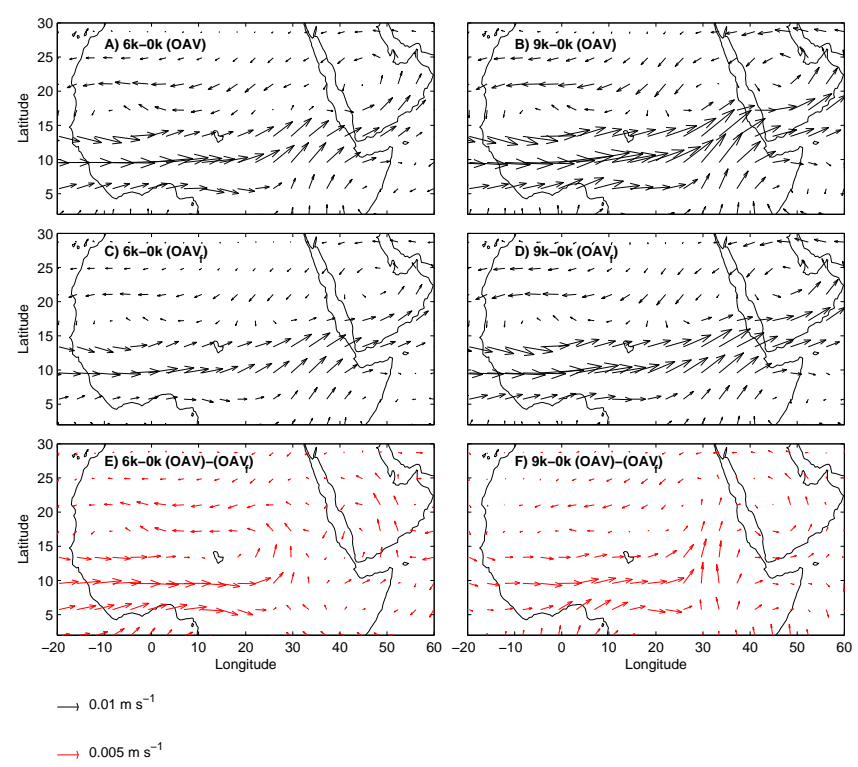

Figure 5. As in Fig. 3 but for changes in summer moisture transport at $700 \mathrm{hPa}$.

A closer inspection of the North African precipitation fields, however, reveals small but statistically significant differences between the experiments $0 \mathrm{k} 9 \mathrm{k}(\mathrm{OAV})$ and $0 \mathrm{k}(\mathrm{OAV})$ in a region between 10 and $15^{\circ} \mathrm{N}$ (Fig. 6a and c). No such coherent pattern is found for the precipitation difference between experiments $6 \mathrm{k} 9 \mathrm{k}(\mathrm{OAV})$ and $6 \mathrm{k}(\mathrm{OAV})$, suggesting that there is no significant influence of the initial vegetation cover on CCSM3-DGVM's simulation of mid-Holocene climate in North Africa (Fig. 6b and c).

\section{Discussion}

In response to enhanced summer insolation, CCSM3-DGVM simulates increased rainfall over North Africa along with a northward shift of the monsoon trough during the early and middle Holocene. In the model experiments, higher rainfall is simulated at $9 \mathrm{ka}$ than at $6 \mathrm{kaBP}$ due to stronger insola- tion forcing. This result should be treated with care, however, since forcings other than orbital and greenhouse gases were not taken into account. In particular, remnants of the Laurentide ice sheet and enhanced meltwater flux into the adjacent ocean might have affected North African rainfall during the early Holocene (Niedermeyer et al., 2009; Lézine et al., 2011; Marzin et al., 2013). Early to mid-Holocene wet conditions are also simulated for southern Arabia in accordance with geological evidence (e.g. McClure, 1976; Hoelzmann et al., 1998; Fleitmann et al., 2003).

The early and mid-Holocene North African precipitation increase goes hand in hand with a northward expansion of the vegetation cover. Substantial greening is also simulated over the Arabian Peninsula in line with vegetation reconstructions (e.g. Hoelzmann et al., 1998). Our sensitivity experiments reveal that the expansion of vegetation acts as a positive feedback on the rainfall increase in both North Africa and the Arabian Peninsula. In the Sahara-Sahel region $\left(10-25^{\circ} \mathrm{N}, 20^{\circ} \mathrm{W}-30^{\circ} \mathrm{E}\right)$ the dynamic vegetation enhances the orbitally triggered rainfall anomaly by approximately $20 \%$ in both the early and mid-Holocene experiments. Despite the enhanced anomalous rainfall when dynamic vegetation is enabled, CCSM3-DGVM still underestimates early to mid-Holocene monsoonal rainfall in the Saharan region by roughly a factor of 2 when compared to mid-Holocene reconstructions (Bartlein et al., 2011). Likewise, the northward expansion of savanna-type vegetation in North Africa also seems to be undersimulated (e.g. Hoelzmann et al., 1998; Jolly et al., 1998; Prentice et al., 2000). Underestimation of the northward extent and intensity of precipitation (and vegetation) changes is a common problem in coupled climate model simulations of the mid-Holocene (e.g. Zheng and Braconnot, 2013), which might reflect shortcomings in physical model parameterizations and/or missing land surface feedbacks (soil, lakes) or could be related to coarse model resolution (Bosmans et al., 2012).

A closer inspection of the mid-tropospheric wind field has identified changes in the AEJ as a key component of the positive vegetation-precipitation feedback mechanism in CCSM3-DGVM. More vegetation north of $15^{\circ} \mathrm{N}$ facilitates 
Table 4. Summer (JJAS) surface albedo values in the early and midHolocene experiments over the region $10-25^{\circ} \mathrm{N}, 20^{\circ} \mathrm{W}-30^{\circ} \mathrm{E}$.

\begin{tabular}{lc}
\hline Experiments & Surface albedo \\
\hline $0 \mathrm{k}(\mathrm{OAV})$ & 0.218 \\
$6 \mathrm{k}(\mathrm{OAV})$ & 0.209 \\
$9 \mathrm{k}(\mathrm{OAV})$ & 0.204 \\
$0 \mathrm{k}\left(\mathrm{OAV}_{\mathrm{f}}\right)$ & 0.217 \\
$6 \mathrm{k}\left(\mathrm{OAV}_{\mathrm{f}}\right)$ & 0.208 \\
$9 \mathrm{k}\left(\mathrm{OAV}_{\mathrm{f}}\right)$ & 0.206 \\
\hline
\end{tabular}

enhanced latent surface cooling through canopy evaporation and transpiration which, according to the thermal wind balance, results in a substantial deceleration of the jet's southern flank associated with a northward AEJ shift. Previous work has shown that a slowdown and/or northward shift of the AEJ is associated with positive Sahelian rainfall anomalies (e.g. Rowell et al., 1992; Xue and Shukla, 1993, 1996; Cook, 1999; Nicholson and Grist, 2001; Rowell, 2003; Cook and Vizy, 2006; Patricola and Cook, 2007; Nicholson, 2008; Bouimetarhan et al., 2012). A latitudinal displacement of the AEJ may affect Sahel rainfall through changes in horizontal and vertical wind shear and associated dynamic instabilities (Grist and Nicholson, 2001; Nicholson and Grist, 2001), a mechanism poorly resolved in coarse-resolution global climate models. Another way to connect changes in the AEJ with rainfall anomalies is through the large-scale column moisture budget (Cook, 1999; Rowell, 2003; Patricola and Cook, 2007; Mulitza et al., 2008). The mid-level jet plays a major role in the North African moisture budget by exporting large amounts of water vapour from the continent to the Atlantic Ocean below the level of condensation. Calculation of horizontal vapour transports in our experiments has revealed a reduction in this moisture export out of the North African realm in the early and middle Holocene. This reduction is amplified by stronger surface cooling in the OAV experiments with dynamic vegetation (Fig. 4e and f) such that more moisture is available to feed the rain in the monsoonal region, providing for a positive vegetation-precipitation feedback.

A positive feedback between the AEJ and sub-Saharan rainfall has been suggested in previous studies (Rowell et al., 1992; Cook, 1999; Rowell, 2003). Our experiments suggest that this feedback is boosted by a dynamic-vegetation cover through modification of surface latent heat fluxes and lowlevel temperature gradients. As such, our results are largely consistent with the regional atmosphere model simulations by Patricola and Cook (2008), who found a close link between Saharan-Sahelian vegetation, North African rainfall, and moisture transports by the AEJ, whereas changes in vegetation have almost no effect on the southerly surface winds from the Gulf of Guinea and the associated near-surface moisture import to the West African monsoon system. However, contrary to Patricola and Cook (2008), who found in-
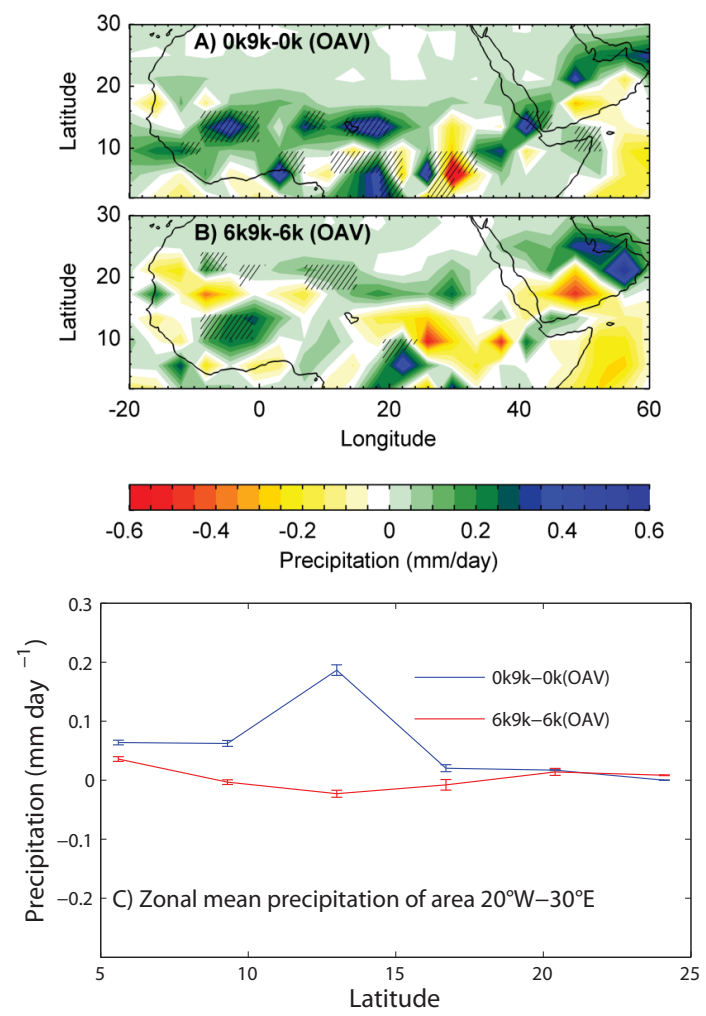

Figure 6. Influence of vegetation initial conditions (9k North African vegetation cover versus bare soil) on pre-industrial and mid-Holocene North African climate simulations. Shown are differences in summer precipitation for (a) $0 \mathrm{k} 9 \mathrm{k}-0 \mathrm{k}(\mathrm{OAV})$ and (b) $6 \mathrm{k} 9 \mathrm{k}-$ $6 \mathrm{k}(\mathrm{OAV})$. Hatched areas display significant precipitation differences (95\% confidence level) according to both a (non-parametric) Wilcoxon-Mann-Whitney test and a Student's $t$ test. The lower panel (c) shows the corresponding zonal averages over North Africa $\left(20^{\circ} \mathrm{W}-30^{\circ} \mathrm{E}\right)$ along with standard errors.

creasing low-level moist static energy and hence increasing convective instability where vegetation expands, changing vegetation has no effect on low-level moist static energy in our CCSM3-DGVM simulations (not shown).

The positive vegetation-precipitation feedback via midtropospheric atmosphere dynamics (AEJ) identified in our model experiments is induced by changes in surface latent heat fluxes. Water vapour, and hence latent heat, is introduced into the atmosphere via plant transpiration and the evaporation of water from the soil and free water on the vegetation canopy (the summed rate is called evapotranspiration). An expanded vegetation cover in North Africa during the early to mid-Holocene favours evapotranspiration (cf. Ripley, 1976). Evapotranspiration increases with precipitation, but the slope is steeper when dynamic vegetation is enabled (Fig. 7). Whether the additional moisture introduced into the atmosphere from the expanded vegetation canopy contributes to enhanced rainfall through local water recycling has been assessed by calculating the Budyko 


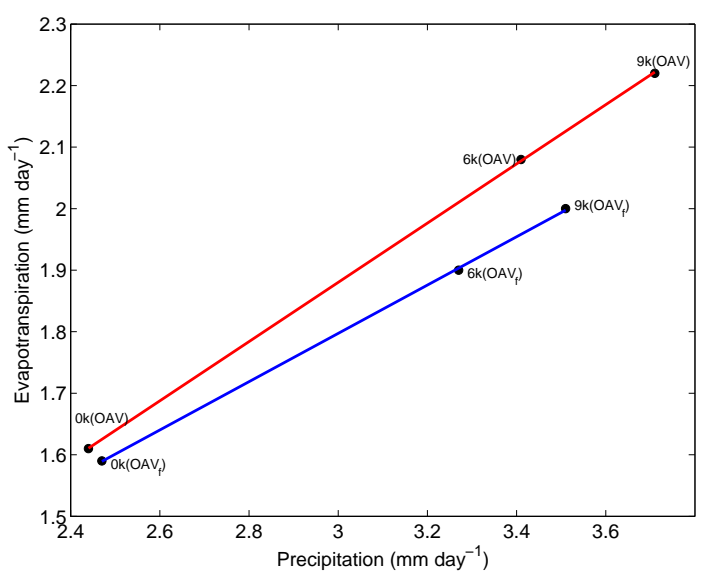

Figure 7. Mean summer evapotranspiration versus precipitation over the region $10-25^{\circ} \mathrm{N}, 20^{\circ} \mathrm{W}-30^{\circ} \mathrm{E}$ in the $0 \mathrm{k}, 6 \mathrm{k}$, and $9 \mathrm{k}$ experiments with dynamic vegetation (OAV experiments; red) and with fixed vegetation $\left(\mathrm{OAV}_{\mathrm{f}}\right.$ experiments; blue).

recycling coefficient (representing the ratio of total precipitation to advected precipitation over a specified area) as defined by Brubaker et al. (1993) for the Sahara-Sahel region (10$\left.25^{\circ} \mathrm{N}, 20^{\circ} \mathrm{W}-30^{\circ} \mathrm{E}\right)$. We found that enhanced water recycling plays no role in the model's positive vegetation-rainfall feedback. For instance, the regional recycling coefficient surprisingly decreases from 1.98 in the pre-industrial control run $0 \mathrm{k}(\mathrm{OAV})$ to 1.59 in the early Holocene experiment $9 \mathrm{k}(\mathrm{OAV})$ when dynamic vegetation is enabled, whereas it increases from 1.66 (pre-industrial) to 2.03 (early Holocene) in the fixed-vegetation experiments $0 \mathrm{k}\left(\mathrm{OAV}_{\mathrm{f}}\right)$ and $9 \mathrm{k}\left(\mathrm{OAV}_{\mathrm{f}}\right)$, respectively.

A closer inspection of the changes in evapotranspiration reveals enhanced evaporative surface cooling due to canopy evaporation and transpiration during the early to mid-Holocene. Model studies that have shown a negative vegetation-precipitation feedback in North Africa (Liu et al., 2007,2010 ) did not include a canopy evaporation term in the formulation of surface hydrology. However, including canopy evaporation in our simulations is crucial for obtaining enough evaporative surface cooling to trigger the positive vegetation-precipitation feedback via mid-tropospheric atmosphere dynamics. In fact, if canopy evaporation was neglected in our simulations (and would not have been compensated for by enhanced transpiration or ground evaporation), the feedback would disappear or even become negative (cf. Table 3).

Vegetation-induced changes in surface albedo (Charney feedback), which would increase low-level moist static energy (resulting in atmospheric destabilization) through enhanced surface warming or, more precisely, less pronounced surface cooling (Charney et al., 1976), play no substantial role in creating a positive vegetation-rainfall feedback in our model study, unlike in earlier studies (e.g. Kutzbach et al., 1996; Claussen and Gayler, 1997; Hales et al., 2006).
By contrast, the positive feedback through AEJ dynamics as found in our study relies on North African surface cooling rather than enhanced surface warming by decreasing surface albedo, consistent with the regional model study by Patricola and Cook (2008). It is important to note that soil albedo values in CCSM3-DGVM depend on the volumetric water content of the first soil layer and can, locally, be as small as 0.09 for saturated soils in the visible range (Oleson et al., 2004). This strongly diminishes the effect of vegetation on North African surface albedo (Levis et al., 2004a; Notaro et al., 2008) as seen in Table 4.

The results from experiments $0 \mathrm{k} 9 \mathrm{k}(\mathrm{OAV})$ and $6 \mathrm{k} 9 \mathrm{k}(\mathrm{OAV})$ suggest that the simulation of modern and mid-Holocene regional climate in North Africa does not depend on the initial vegetation cover, as also shown by Renssen et al. (2006b). Despite the existence of a positive vegetation-rainfall feedback multiple equilibrium states were not found on the regional scale, which would rule out the potential for abrupt climate-vegetation transitions in the Holocene due to a catastrophic bifurcation or "unstable collapse" (Liu et al., 2006, 2007). However, statistical significance tests did not rule out the possibility of multiple states on the local scale between 10 and $15^{\circ} \mathrm{N}$ under modern boundary conditions. This implies that, locally, unstable collapses could occur such that late Holocene proxy records from specific sites may show abrupt transitions while records from other sites do not (cf. Bathiany et al., 2012). Similar ideas were put forward by Brovkin and Claussen (2008), Williams et al. (2011) and Claussen et al. (2013). For the middle Holocene, the climate-vegetation system turned out to be monostable in CCSM3-DGVM even on the local scale, which is consistent with earlier findings by Brovkin et al. (1998) who suggested that the system is prone to bistability only in the late Holocene, whereas the early to mid-Holocene was monostable.

\section{Conclusions}

Model experiments with CCSM3-DGVM support the findings of increased summer rainfall and expansion of vegetation in the early to mid-Holocene over North Africa as in previous coupled general circulation model studies. By enabling interactive dynamic vegetation (OAV experiments), rainfall intensification is much more pronounced in this model. In the Sahara-Sahel region, the dynamic vegetation enhances the orbitally triggered summer rainfall anomaly by approximately $20 \%$ in both the early (9 ka BP) and mid-Holocene (6 ka BP) experiments.

The primary vegetation-atmosphere feedback identified here operates through surface latent heat flux anomalies by canopy evapotranspiration and their effect on the AEJ. As such, the vegetation feedback relies on enhanced surface (evaporational) cooling as opposed to the Charney feedback which operates through atmospheric instability by decreased surface albedo. Neglecting canopy evaporation, as 
in some previous model studies, could substantially affect the simulation of evaporative cooling such that the positive vegetation-atmosphere feedback might disappear. This type of climate-vegetation feedback over North Africa does not apply to other monsoon regions, since the feedback mechanism is closely linked to the characteristics of the regional atmospheric circulation (e.g. the presence of the AEJ). However, the North African climate-vegetation feedback should work also in epochs other than the Holocene. Even though CCSM3-DGVM simulates a positive vegetationprecipitation feedback over North Africa, this feedback is not strong enough to produce multiple equilibrium climateecosystem states on a regional scale.

In order to cope with the uncertainties regarding the potential model dependencies, further sensitivity studies are needed to assess the robustness of our results. Besides model resolution and PFT characteristics in the vegetation model, sensitivity studies should particularly address the effects of different parameterizations for land surface evaporation, transpiration, and albedo.

Acknowledgements. This study has been supported by the Deutsche Forschungsgemeinschaft (DFG) through the Priority Programme INTERDYNAMIC. The CCSM3-DGVM model simulations have been carried out on the HLRN-II (SGI Altix) supercomputer.

Edited by: U. Herzschuh

\section{References}

Bartlein, P. J., Harrison, S. P., Brewer, S., Connor, S., Davis, B. A. S., Gajewski, K., Guiot, J., Harrison-Prentice, T. I., Henderson, A., Peyron, O., Prentice, I. C., Scholze, M., Seppa, H., Shuman, B., Sugita, S., Thompson, R. S., Viau, A. E., Williams, J., and $\mathrm{Wu}, \mathrm{H}$.: Pollen-based continental climate reconstructions at 6 and $21 \mathrm{ka}$ : A global synthesis, Clim. Dynam., 37, 775-802, 2011.

Bathiany, S., Claussen, M., and Fraedrich, K.: Implications of climate variability for the detection of multiple equilibria and for rapid transitions in the atmosphere-vegetation system, Clim. Dynam., 38, 1775-1790, 2012.

Berger, A.: Long-term variations of daily insolation and Quaternary climatic change, J. Atmos. Sci., 35, 2362-2367, 1978.

Beyerle, U., Rueedi, J., Leuenberger, M., Aeschbach-Hertig, W., Peeters, F., Kipfer, R., and Dodo, A.: Evidence for periods of wetter and cooler climate in the Sahel between 6 and 40 kyr BP derived from groundwater, Geophys. Res. Lett., 30, 1173, doi:10.1029/2002GL016310, 2003.

Bonan, G. B. and Levis, S.: Evaluating aspects of the Community Land and Atmosphere Models (CLM3 and CAM) using a dynamic global vegetation model, J. Climate, 19, 2290-2301, 2006.

Bonan, G. B., Levis, S., Sitch, S., Vertenstein, M., and Oleson, K. W.: A dynamic global vegetation model for use with climate models: concepts and description of simulated vegetation dynamics, Glob. Change Biol., 9, 1543-1566, 2003.

Bosmans, J. H. C., Drijfhout, S. S., Tuenter, E., Lourens, L. J., Hilgen, F. J., and Weber, S. L.: Monsoonal response to mid- holocene orbital forcing in a high resolution GCM, Clim. Past, 8, 723-740, doi:10.5194/cp-8-723-2012, 2012.

Bouimetarhan, I., Prange, M., Schefuss, E., Dupont, L., Lippold, J., Mulitza, S., and Zonneveld, K.: Sahel megadrought during Heinrich Stadial 1: evidence for a three-phase evolution of the low- and mid-level West African wind system, Quaternary Sci. Rev., 58, 66-76, 2012.

Braconnot, P., Otto-Bliesner, B., Harrison, S., Joussaume, S., Peterchmitt, J.-Y., Abe-Ouchi, A., Crucifix, M., Driesschaert, E., Fichefet, Th., Hewitt, C. D., Kageyama, M., Kitoh, A., Laîné, A., Loutre, M.-F., Marti, O., Merkel, U., Ramstein, G., Valdes, P., Weber, S. L., Yu, Y., and Zhao, Y.: Results of PMIP2 coupled simulations of the Mid-Holocene and Last Glacial Maximum Part 1: experiments and large-scale features, Clim. Past, 3, 261277, doi:10.5194/cp-3-261-2007, 2007.

Brovkin, V. and Claussen, M.: Comment on climate-driven ecosystem succession in the Sahara: The past 6000 years, Science, 322, 1326, doi:10.1126/science.1163381, 2008.

Brovkin, V., Claussen, M., Petoukhov, V., and Ganopolski, A.: On the stability of the atmosphere-vegetation system in the Sahel/Sahara region, J. Geophys. Res., 103, 31613-31624, 1998.

Brubaker, K. L., Entekhabi, D., and Eagleson, P. S.: Estimation of continental precipitation recycling, J. Climate, 6, 1077-1089, 1993.

Charney, J. G.: Dynamics of deserts and drought in the Sahel, Q. J. Roy. Meteor. Soc., 101, 193-202, 1975.

Charney, J. G., Stone, P. H., and Quirk, W. J.: Reply, Science, 191, 100-102, 1976.

Chen, G. S, Kutzbach, J. E, Gallimore, R., and Liu, Z.: Calendar effect on phase study in paleoclimate transient simulation with orbital forcing, Clim. Dynam., 37.9-10, 1949-1960, doi:10.1007/s00382-010-0944-6, 2011.

Claussen, M.: On coupling global biome models with climate models, Clim. Res., 4, 203-221, 1994.

Claussen, M.: Modelling biogeophysical feedback in the African and Indian Monsoon region, Clim. Dynam., 13, 247-257, 1997.

Claussen, M.: On multiple solutions of the atmosphere-vegetation system in present-day climate, Glob. Change Biol., 5, 549-559, 1998.

Claussen, M.: Late Quaternary vegetation-climate feedbacks, Clim. Past, 5, 203-216, doi:10.5194/cp-5-203-2009, 2009.

Claussen, M. and Gayler, V.: The greening of Sahara during the mid-Holocene: Results of an interactive atmosphere-biome model, Global Ecol. Biogeogr., 6, 369-377, 1997.

Claussen, M., Brovkin, V., Ganopolski, A., Kubatzki, C., and Petoukhov, V.: Modeling global terrestrial vegetationclimate interaction, Philos. T. R. Soc. Lon. B, 353, 53-56, doi:10.1098/rstb.1998.0190, 1998.

Claussen, M., Kubatzki, C., Brovkin, V., Ganopolski, A., Hoelzmann, P., and Pachur, H. J.: Simulation of an abrupt change in Saharan vegetation in the mid-Holocene, Geophys. Res. Lett., 26, 2037-2040, doi:10.1029/1999GL900494, 1999.

Claussen, M., Bathiany, S., Brovkin, V., and Kleinen, T.: Simulated climate-vegetation interaction in semi-arid regions affected by plant diversity, Nat. Geosci., 6, 954-958, 2013.

Coe, M. and Bonan, G.: Feedbacks between climate and surface water in northern Africa during the middle Holocene, J. Geophys. Res., 102, 11087-11101, doi:10.1029/97JD00343, 1997. 
Collins, W. D., Bitz, C. M., Blackmon, M. L., Bonan, G. B., Bretherton, C. S., Carton, J. A., Chang, P., Doney, S. C., Hack, J. J., Henderson, T. B., Kiehl, J. T., Large, W. G., McKenna, D. S., Santer, B. D., and Smith, R. D.: The Community Climate System Model version 3 (CCSM3), J. Climate, 19, 2122-2143, 2006.

Collins, J. A., Schefuss, E., Mulitza, S., Prange, M., Werner, M., Tharammal, T., Paul, A., and Wefer, G.: Estimating the hydrogen isotopic composition of past precipitation using leaf-waxes from western Africa, Quaternary Sci. Rev., 65, 88-101, 2013.

Cook, K. H.: Generation of the African easterly jet and its role in determining west African precipitation, J. Climate, 12, 1165-1184, 1999.

Cook, K. H. and Vizy, E. K.: Coupled model simulations of the West African monsoon system: Twentieth- and twenty-first-century simulations, J. Climate, 19, 3681-3703, 2006.

DeFries, R. S., Townshend, J. R. G., and Hansen, M. C.: Continuous fields of vegetation characteristics at the global scale at $1 \mathrm{~km}$ resolution, J. Geophys. Res., 104, 16911-16925, 1999.

DeFries, R. S., Hansen, M. C., Townshend, J. R. G., Janetos, A. C., and Loveland, T. R.: A new global 1-km dataset of percentage tree cover derived from remote sensing, Glob. Change Biol., 6, 247-254, 2000.

deMenocal, P., Ortiz, J., Guilderson, T., Adkins, J., Sarnthein, M., Baker, L., and Yarusinsky, M.: Abrupt onset and termination of the African Humid Period: Rapid climate responses to gradual insolation forcing, Quaternary Sci. Rev., 19, 347-361, 2000.

Doherty, R. M., Kutzbach, J., Foley, J., and Pollard, D.: Fully- coupled climate/dynamical vegetation model simulations over northern Africa during the mid-Holocene, Clim. Dynam., 16, 561567, 2000.

Fleitmann, D., Burns, S. J., Mudelsee, M., Neff, U., Kramers, J., Mangini, A., and Matter, A.: Holocene forcing of the Indian monsoon recorded in a stalagmite from southern Oman, Science, 300, 1737-1739, 2003.

Francus, P., von Suchodoletz, H., Dietze, M., Donner, R. V., Bouchard, F., Roy, A.-J., Fagot, D., Verschuren, D., and Kröpelin, S.: Varved sediments of Lake Yoa (Ounianga Kebir, Chad) reveal progressive drying of the Sahara during the last 6100 years, Sedimentology, 60, 911-934, doi:10.1111/j.13653091.2012.01370.x, 2013.

Grist, J. P. and Nicholson, S. E.: A study of the dynamic factors influencing the interannual variability of rainfall in the West African Sahel, J. Climate, 14, 1337-1359, 2001.

Hales, K., Neelin, J. D., and Zeng, N.: Interaction of vegetation and atmospheric dynamical mechanisms in the mid-Holocene African monsoon, J. Climate, 19, 4105-4120, 2006.

Handiani, D., Paul, A., Prange, M., Merkel, U., Dupont, L., and Zhang, X.: Tropical vegetation response to Heinrich Event 1 as simulated with the UVic ESCM and CCSM3, Clim. Past, 9, 1683-1696, doi:10.5194/cp-9-1683-2013, 2013.

Hoelzmann, P., Jolly, D., Harrison, S. P., Laarif, F., Bonnefille, R., and Pachur, H. J.: Mid-Holocene land surface conditions in northern Africa and the Arabian Peninsula: A data set for the analysis of biogeochemical feedbacks in the climate system, Global Biogeochem. Cy., 12, 35-52, 1998.

Jolly, D., Harrison, S. P., Damnati, B., and Bonnefille, R.: Simulated climate and biomes of Africa during the Late Quaternary: comparison with pollen and lake status data, Quaternary Sci. Rev., 17, 629-657, 1998.
Joussaume, S. and Braconnot, P.: Sensitivity of paleoclimate simulation results to season definitions, J. Geophys. Res., 102, 19431956, 1997.

Kohfeld, K. E. and Harrison, S. P.: How well can we simulate past climates?, Evaluating the models using global palaeoenvironmental datasets, Quaternary Sci. Rev., 19, 321-345, 2000.

Krinner, G., Lézine, A.-M., Braconnot, P., Sepulchre, P., Ramstein, G., Grenier, C., and Gouttevin, I.: A reassessment of lake and wetland feedbacks on the North African Holocene climate, Geophys. Res. Lett., 39, L07701, doi:10.1029/2012GL050992, 2012.

Kröpelin, S., Verschuren, D., Lézine, A.-M., Eggermont, H., Cocquyt, C., Francus, P., Cazet, J.-P., Fagot, M., Rumes, B., Russell, J. M., Darius, F., Conley, D. J., Schuster, M., von Suchodoletz, H., and Engstrom, D. R.: Climate-driven ecosystem succession in the Sahara: The past 6000 years, Science, 320, 765-768, 2008.

Kutzbach, J. E.: Monsoon climate of the early Holocene: Climate experiment with the Earth's orbital parameters for 9000 years ago, Science, 214, 59-61, 1981.

Kutzbach, J. E. and Street-Perrot, E. A.: Milankovitch forcing of fluctuations in the level of tropical lakes from 18 to $0 \mathrm{ka}$, Nature, 317, 130-134, 1985.

Kutzbach, J. E. and Liu, Z.: Response of the African monsoon to orbital forcing and ocean feedbacks in the middle Holocene, Science, 278, 440-444, 1997.

Kutzbach, J. E., Bonan, G., Foley, J., and Harrison, S. P.: Vegetation/soil feedbacks and African monsoon response to orbital forcing in the Holocene, Nature, 384, 623-626, 1996.

Lawrence, P. J. and Chase, T. N.: Representing a new MODIS consistent land surface in the Community Land Model (CLM3.0), J. Geophys. Res., 112, G01023, doi:10.1029/2006JG000168, 2007.

Levis, S., Bonan, G. B., and Bonfils, C.: Soil feedback drives the mid-Holocene North African monsoon northward in fully coupled CCSM2 simulations with a dynamic vegetation model, Clim. Dynam., 23, 791-802, 2004a.

Levis, S., Bonan, G. B., Vertenstein, M., and Oleson, K. W.: The Community Land Model's Dynamic Global Vegetation Model (CLM-DGVM): Technical description and user's guide, NCAR Technical Note NCAR/TN-459+IA, National Center for Atmospheric Research, Boulder, CO, 50 pp., 2004b.

Lézine, A., Hély, C., Grenier, C., Braconnot, P., and Krinner, G.: Sahara and Sahel vulnerability to climate changes, lessons from Holocene hydrological data, Quaternary Sci. Rev., 30, 30013012, 2011.

Liu, Z., Wang, Y., Gallimore, R., Notaro, M., and Prentice, C. I.: On the mechanism of abrupt change of northern Africa environment in the Holocene: climate variability vs. vegetation feedback, Geophys. Res. Lett., 33, L22709, doi:10.1029/2006GL028062, 2006.

Liu, Z., Wang, Y., Gallimore, R., Gasse, F., Johnson, T., deMenocal, P., Adkins, J., Notaroa, M., Prentice, I. C., Kutzbach, J., Jacob, R., Behling, P., Wang, L., and Ong, E.: Simulating the transient evolution and abrupt change of northern Africa atmosphereocean-terrestrial ecosystem in the Holocene, Quaternary Sci. Rev., 26, 1818-1837, 2007.

Liu, Z., Notaro, M., and Gallimore, R.: Indirect vegetation soil moisture feedback with application to Holocene North Africa climate, Glob. Change Biol., 16, 1733-1743, 2010.

Marzin, C., Braconnot, P., and Kageyama, M.: Relative impacts of insolation changes, meltwater fluxes and ice sheets on African 
and Asian monsoons during the Holocene, Clim. Dynam., 41, 2267-2286, 2013.

McClure, H. A.: Radiocarbon chronology of late Quaternary lakes in the Arabian desert, Nature, 263, 755-756, 1976.

Mulitza, S., Prange, M., Stuut, J. B., Zabel, M., von Dobeneck, T., Itambi, C. A., Nizou, J., Schulz, M., and Wefer, G.: Sahel megadroughts triggered by glacial slowdowns of Atlantic meridional overturning, Paleoceanography, 23, PA4206, doi:10.1029/2008PA001637, 2008.

Nicholson, S. E.: The intensity, location and structure of the tropical rainbelt over West Africa as a factor in interannual variability, Int. J. Climatol., 28, 1775-1785, 2008.

Nicholson, S. E. and Grist, J. P.: A conceptual model for understanding rainfall variability in the West African Sahel on interannual and interdecadal timescales, Int. J. Climatol., 21, 17331757,2001

Niedermeyer, E. M., Prange, M., Mulitza, S., Mollenhauer, G., Schefuss, E., and Schulz, M.: Extratropical forcing of Sahel aridity during Heinrich stadials, Geophys. Res. Lett., 36, L20707, doi:10.1029/2009GL039687, 2009.

Notaro, M., Wang, Y., Liu, Z., Gallimore, R., and Levis, S.: Combined statistical and dynamical assessment of simulated vegetation-rainfall interactions in North Africa during the midHolocene, Glob. Change Biol., 14, 347-368, 2008.

Oleson, K. W., Dai, Y., Bonan, G., Dickinson, R. E., Dirmeyer, P. A., Hoffman, F., Houser, P., Levis, S., Niu, G.-Y., Thornton, P., Vertenstein, M., Yang, Z.-L., and Zeng, X.: Technical description of the Community Land Model (CLM), Tech. Rep. NCAR/TN461, National Center for Atmospheric Research, Boulder, CO, 174 pp., 2004.

Oleson, K. W., Niu, G. Y., Yang, Z. L., Lawrence, D. M., Thornton, P. E., Lawrence, P. J., Stockli, R., Dickinson, R. E. G., Bonan, B., Levis, S., Dai, A., and Qian, T.: Improvements to the Community Land Model and their impact on the hydrological cycle, J. Geophys. Res., 113, G01021, doi:10.1029/2007JG000563, 2008.

Otterman, J.: Baring high-albedo soils by overgrazing: a hypothesised desertification mechanism, Science, 186, 531-533, 1974.

Otto-Bliesner, B. L., Tomas, R., Brady, E. C., Ammann, C., Kothavala, Z., and Clauzet, G.: Climate sensitivity of moderate and low-resolution versions of CCSM3 to preindustrial forcings, J. Climate, 19, 2567-2583, 2006.

Patricola, C. M. and Cook, K. H.: Dynamics of the West African monsoon under mid-Holocene precessional forcing: Regional climate model simulations, J. Climate, 20, 694-716, 2007.

Patricola, C. M. and Cook, K. H.: Atmosphere/vegetation feedbacks: A mechanism for abrupt climate change over northern Africa, J. Geophys. Res., 113, D18102, doi:10.1029/2007JD009608, 2008.

Prentice, I. C. and Jolly, D.: BIOME 6000 participants: MidHolocene and glacial-maximum vegetation geography of the northern continents and Africa, J. Biogeogr., 27, 507-519, 2000.

Renssen, H., Brovkin, V., Fichefet, T., and Goosse, H.: Holocene climate instability during the termination of the African Humid Period, Geophys. Res. Lett., 30, 1184, doi:10.1029/2002GL016636, 2003.

Renssen, H., Brovkin, V., Fichefet, T., and Goosse, H.: Simulation of the Holocene climate evolution in northern Africa: The termination of the African Humid Period, Quatern. Int., 150, 95-102, 2006a.
Renssen, H., Driesschaert, E., Loutre, M. F., and Fichefet, T.: On the importance of initial conditions for simulations of the midHolocene climate, Clim. Past, 2, 91-97, doi:10.5194/cp-2-912006, 2006b.

Ripley, E. A.: Drought in the Sahara: insufficient bio-geophysical feedback?, Science, 191, 100-102, doi:10.1126/science.191.4222.100, 1976.

Rowell, D. P.: The impact of Mediterranean SSTs on the Sahelian rainfall season, J. Climate, 16, 849-862, 2003.

Rowell, D. P., Folland, C. K., Maskell, K., Owen, J. A., and Ward, M. N.: Modelling the influence of global sea surface temperatures on the variability and predictability of seasonal Sahel rainfall, Geophys. Res. Lett., 19, 905-908, 1992.

Sitch, S., Smith, B., Prentice, I. C., Arneth, A., Bondeau, A., Cramer, W., Kaplan, J. O., Levis, S., Lucht, W., Sykes, M. T., Thonicke, K., and Venevsky, S.: Evaluation of ecosystem dynamics, plant geography and terrestrial carbon cycling in the LPJ dynamic vegetation model, Glob. Change Biol., 9, 161-185, 2003.

Street-Perrott, F. A. and Perrott, R. A.: Holocene vegetation, lake levels and climate of Africa, in: Global climates since the Last Glacial Maximum, University of Minnesota Press, Minneapolis, 318-356, 1993.

Wang, G. and Eltahir, E. A. B.: Biosphere-atmosphere interactions over West Africa, II: Multiple climate equilibria, Q. J. Roy. Meteor. Soc., 126, 1261-1280, 2000.

Wang, Y., Notaro, M., Liu, Z., Gallimore, R., Levis, S., and Kutzbach, J. E.: Detecting vegetation-precipitation feedbacks in mid-Holocene North Africa from two climate models, Clim. Past, 4, 59-67, doi:10.5194/cp-4-59-2008, 2008.

Williams, J. W., Blois, J. L., and Shuman, B. N.: Extrinsic and intrinsic forcing of abrupt ecological change: case studies from the late Quaternary, J. Ecol., 99, 664-677, 2011.

Xue, Y. and Shukla, J.: The influence of land-surface properties on Sahel climate, Part 1: Desertification, J. Climate, 6, 2232-2245, 1993.

Xue, Y. and Shukla, J.: The influence of land surface properties on Sahel climate, Part II: Afforestation, J. Climate, 9, 3260-3275, 1996.

Yeager, S. G., Shields, C. A., Large, W. G., and Hack, J. J.: The low-resolution CCSM3, J. Climate, 19, 2545-2566, 2006.

Zeng, N. and Neelin, J. D.: The role of vegetation-climate interaction and interannual variability in shaping the African savanna, J. Climate, 13, 2665-2670, 2000.

Zhao, Y. and Harrison, S. P.: A multi-model analysis of the role of the ocean on the African and Indian monsoon during the midHolocene, Clim. Dynam., 39, 1457-1487, 2012.

Zhao, Y., Braconnot, P., Marti, O., Harrison, S. P., Hewitt, C., Kitoh, A., Liu, Z., Mikolajewicz, U., Otto-Bliesner, B., and Weber, S. L.: A Multi-Model Analysis of the Role of the Ocean on the African and Indian Monsoon During the Mid-Holocene, Clim. Dynam., 25, 777-800, 2005.

Zheng, W. and Braconnot, P.: Characterization of model spread in PMIP2 mid-Holocene simulations of the African monsoon, J. Climate, 26, 1192-1210, 2013. 